Anna RYŚ

\title{
CHRZEŚCIJAŃSKA INTERPRETACJA KILKU ANTYCZNYCH GEMM
}

Postawa chrześcijaństwa wobec spadku przejętego z kultury pogańskiego antyku nie była jednoznaczna. Choć w religii zdecydowanie odwracano się od przeszłości, to w dziedzinie sztuki, a zwłaszcza literatury, piękno pozostawionych przez starożytność dzieł niekiedy tak fascynowało, że przejmowano je do nowej, tworzącej się tradycji. Najbardziej spektakularnym tego przykładem jest Wergiliusz, którego dzięki IV eklodze można było uznać za Christianus sine Christo.

Dzieła sztuki bezpośrednio związane z kultem pogańskim znajdowały się poza kręgiem ewentualnych translacji z greckiego i rzymskiego antyku do chrześcijańskiej kultury. Inaczej przedstawiała się sytuacja obiektów, które takiego związku nie wykazywały lub przynajmniej wraz z upływem czasu i zwycięskim rozprzestrzenianiem się nowej religii, związek ten przestawał być zauważalny. Wśród tego rodzaju odziedziczonych przez chrześcijaństwo dzieł znaczące miejsce zajmowały antyczne gemmy. Liczba ich była ogromna. Kazali je tworzyć wybitnym gliptykom cesarze, aby uwiecznić siebie, swoją rodzinę, czy jakieś ważne polityczne wydarzenia. Ale potrzebowali ich również całkiem przeciętni obywatele imperium, którzy wklęsło rzeźbione w kamieniach (intaglio) rozmaite przedstawienia nosili w pierścieniach jako znaki własnościowe służące za swoisty rodzaj podpisu.

Chrześcijanie początkowo mieli pewne opory przed korzystaniem z gemm pozostawionych przez pogańskich twórców. Jednak już Klemens Aleksandryjski (ok. 140 - ok. 215) starał się rozproszyć ich obawy zalecając tylko, aby wybierali z dzieł gliptycznych takie, które mają wizerunki stosowne dla wyznawanej przez nich wiary. Odpowiednie zatem miały być sygnety z gołębiem, rybą, statkiem, lirą, rybakiem, czy kotwicą ${ }^{1}$. W średniowieczu, kiedy kulty pogańskie odeszły w przeszłość, gemmami antycznymi, ze względu na piękno ich wykonania, wartość kamieni, a także poczucie przejmowania dzięki nim chwały, jaką cieszyli się władcy dawnego imperium, często ozdabiano różne obiekty, w tym relikwiarze oraz krzyże ${ }^{2}$. Niejednokrotnie zdarzało się,

* Dr hab. Anna Ryś, prof. UG - profesor nadzwyczajny w Katedrze Filologii Klasycznej na Wydziale Filologicznym Uniwersytetu Gdańskiego; e-mail: filrs@ug.edu.pl.

${ }^{1}$ Por. Clemens Alexandrinus, Paedagogus III 11, 59.

${ }^{2}$ Ciekawym tego przykładem jest m.in. tzw. Krzyż Dezyderiusza z Brescii, por. G. Sena Chiesa, 
że nie rozumiano ich ikonografii i odczytywano jako przedstawienia postaci znanych $\mathrm{z}$ tradycji biblijnej. Kamienie $\mathrm{z}$ wygrawerowanym wizerunkiem Serapisa uznawano za portret Jezusa. Wiadomo, że taki właśnie sygnet nosił Karol Wielki . Jowisz z towarzyszącym mu orłem stawał się Janem Ewangelista, a Muza tragedii, Melpomena, z powodu trzymanego przez nią atrybutu, teatralnej maski, uchodziła za Herodiadę z głową Jana Chrzciciela ${ }^{4}$. Nie zawsze jednak przyczyny, które wywołały włączenie pogańskiego dzieła gliptycznego do tradycji chrześcijańskiej, są tak łatwe do wyjaśnienia.

Przedmiotem poniższych rozważań będą cztery antyczne gemmy, znajdujące się obecnie w zbiorach Gabinetu Medali francuskiej Biblioteki Narodowej, które w epoce średniowiecza uległy „chrystianizacji” i zdobiły obiekty religijne złożone w paryskiej Sainte-Chapelle, w katedrze w Chartres oraz w opactwie Saint-Denis.

1. Wielka Kamea Francji. Do najbardziej znanych antycznych gemm, które w czasach średniowiecznych włączone zostały w krąg tradycji chrześcijańskiej, należy tzw. Wielka Kamea Francji'. Nazwę zawdzięcza swoim nadzwyczajnym rozmiarom ${ }^{6}$. Była bowiem i nadal jest największą ze znajdujących się w zbiorach muzealnych kamei. Wyrzeźbiona została w sardonyksie o pięciu warstwach. Maksymalne wymiary kamienia to $31 \mathrm{~cm}$ wysokości i $26,5 \mathrm{~cm}$ szerokości 7 .

Gemma po raz pierwszy odnotowana została w spisie skarbca Sainte-Chapelle pochodzącym sprzed roku $1279^{8}$. Uważa się, że najprawdopodobniej znajdowała się wśród relikwii, które Ludwik IX (1226-1270) otrzymał w 1247 r. od Baldwina II de Courtenay (1228-1261), ostatniego łacińskiego cesarza Konstantynopola. Baldwin II, którego panowanie było zagrożone przez Bizantyjczyków dążących do odbudowy rozbitego w 1204 r. Cesarstwa, szukał pomocy finansowej i militarnej u katolickich władców Europy. Król Francji

Nova gloria vetustatis. Intailles et camées dans la Croix de Didier de Brescia, w: La glyptique des mondes classiques. Mélanges en hommage à Marie-Louise Vollenweider, textes réunis par M. Aviseau Broustet, Paris 1997, 97-117.

${ }^{3}$ Por. C.W. King, Antique Gems, their Origin, Uses, and Value as Interpreters of Ancient History, and as Illustrative of Ancient Art., London 1860, 325.

${ }^{4}$ Por. tamże, s. 302.

${ }^{5}$ Określana była także jako Agat z Sainte-Chapelle, a od początku XVII w., kiedy odkryto jej przynależność do czasów początku dynastii julijsko-klaudyjskiej-Gemma Tiberiana (na wzór sławnej Gemma Augustea z Wiednia), Apoteoza Augusta lub Gloryfikacja Germanika.

${ }^{6}$ Już w 1484 r. opisana została jako grand camaïeu, ,,wielka kamea” (M. du Mersan, Histoire du Cabinet des Médailles, Antiques et Pierres Gravées, avec une notice sur la Bibliothèque Royale et une description des objets exposés dans cet établissement, Paris 1838, 3), a w inwentarzu skarbca Sainte-Chapelle z 1573 r. nazwano ją: ung beau grand camahieu, ,jedna piękna wielka kamea” (E. Babelon, Catalogue des camées antiques et modernes de la Bibliothèque Nationale, Paris 1897, 128).

${ }^{7}$ Por. M.-L. Vollenweider - M. Aviseau-Broustet, Camées et intailles, t. 2: Les Portraits du Cabinet des médailles. Catalogue raisonné. Texte, Paris 2003, 219.

${ }^{8}$ Por. tamże. 
obiecał mu ją w zamian za przekazanie znajdujących się w pałacu konstantynopolitańskim relikwii Męki Pańskiej ${ }^{9}$. W celu zapewnienia im godnego miejsca kultu Ludwik IX wzniósł na wyspie Cité, w pobliżu swojego zamku, Sainte-Chapelle. Ponieważ wśród przekazanych przez Baldwina II dwudziestu dwóch relikwii ${ }^{10}$ nie jest wymieniona kamea $\mathrm{z}$ sardonyksu, badacze dziejów tego zabytku wysuwają przypuszczenie, że nie mieściła się ona w tej grupie, a była jednym $z$ dodatkowych darów, ewentualnie obiektów sprzedanych królowi Ludwikowi. Należy jednak zwrócić uwagę, że spisy relikwii ograniczają się do ich wyliczania i nie zawierają wiadomości o ewentualnych relikwiarzach, w jakich mogły być one umieszczone. Wielka Kamea w momencie przybycia do Paryża była zaś centralnym elementem ozdobnego relikwiarza i nie można wykluczyć, że zawierała w swojej oprawie któreś z obiektów wymienionych w liście Baldwina II. Wartość opraw relikwii, nawet wykonanych ze szlachetnych metali i drogocennych kamieni, w średniowieczu zawsze ustępowała wartości samych relikwii, które w nich chroniono.

Do roku 1620 usytuowana w centralnej części relikwiarza kamea uchodziła za dzieło sztuki o tematyce biblijnej. Uważano, że scena wyrzeźbiona w sardonyksie przedstawia tryumfy Józefa, syna Jakuba, na dworze faraona Egiptu. Przez krótki czas obiekt przebywał poza królestwem Francji. Dotknięty bowiem problemami finansowymi pierwszy z Walezjuszy, Filip VI (1328-1350), zastawił go u papieża Klemensa VI (1342-1352) wkrótce po 1341 r. (w sporządzonym w tym roku inwentarzu skarbca kamea była jeszcze uwzględniona) ${ }^{11}$. Okazja do odzyskania cennego dzieła nadarzyła się, gdy z kolei papieże awiniońscy w wyniku schizmy zachodniej potrzebowali finansowego i politycznego wsparcia królów Francji. W tej korzystnej dla Walezjuszy sytuacji kamea została zwrócona Karolowi V Mądremu (1364-1380), który przekazał ją ponownie do Sainte-Chapelle. Aby upamiętnić jej odzyskanie, władca nakazał osadzić pochodzącą jeszcze z Bizancjum oprawę na podstawie ozdobionej wizerunkami dwunastu apostołów, a na cokole umieścić napis, który głosił, że to on w roku 1379 oddał kameę do kaplicy.

Relikwiarz i kamea $\mathrm{z}$ - jak mniemano - sceną biblijną była przedmiotem kultu. Podczas religijnych uroczystości ukazywano ją oczom wiernych. Wiadomo też, że była w 1484 r. niesiona w procesji z okazji koronacji Karola VIII (1483-1498).

\footnotetext{
${ }^{9}$ Religijne i polityczno-kulturalne podłoże, na gruncie którego nastąpiło sprowadzenie relikwii przez Ludwika IX przedstawia w swojej doskonałej pracy Jerzy Pysiak (Król i Korona Cierniowa. Kult relikwii we Francji Kapetyngów, Warszawa 2012).

${ }^{10}$ Najcenniejszymi z nich były Korona Cierniowa i drewno Prawdziwego Krzyża; pełna lista relikwii por. Le trésor de la Sainte-Chapelle. Paris, Musée du Louvre, 31 mai 2001 - 27 août 2001, éd. J. Durand - M.-P. Lafitte, Paris 2001, 32, 49-50.

${ }^{11}$ Opis losów kamei oraz jej oprawy najpełniej przedstawił Babelon, Catalogue des camées, s. 125-136.
} 
Przekonanie, że kamea przedstawia tryumfy Józefa w Egipcie upadło w 1620 r. Wybitny prowansalski erudyta Nicolas-Claude Fabri de Peiresc stwierdził wówczas, że na gemmie przedstawiony został cesarz Tyberiusz (14-37), który w towarzystwie matki Liwii przyjmuje swojego powracającego z wyprawy wojennej bratanka Germanika. Trafną identyfikację głównych postaci zawdzięczał de Peiresc doskonałej znajomości rzymskich monet. O ile uznanie dwóch z trzech centralnych postaci ze środkowej strefy kamei (przedstawienie dzieli się na trzy poziome strefy) za Tyberiusza i Liwię nie wywołuje kontrowersji, to przydzielenie odpowiedniego imienia każdej z dwudziestu czterech figur wyrzeźbionych w sardonyksie, nie jest bezdyskusyjne. Próby odczytania różnią się między sobą ${ }^{12}$. Wystarczy nadmienić, że niektórzy badacze widzą w stojącym przed cesarzem dowódcy nie Germanika, lecz jego najstarszego syna Nerona, inni Kaligulę, a jeszcze inni syna Tyberiusza, Druzusa. Podobnie centralna postać strefy najwyższej odczytywana bywa jako ubóstwiony cesarz August lub jego adopcyjny ojciec, Juliusz Cezar.

W konsekwencji takich rozbieżności również datacja kamei nie jest ścisła. Nie ma zgodności co do tego, czy miała upamiętnić współczesne jej wydarzenia, czy może pełnić funkcję kommemoratywną. W tym drugim przypadku byłaby datowana na czasy rządów Kaliguli (37-41). Jeśli wykonana została za panowania Tyberiusza, a podejmowanym wodzem jest jego bratanek, to w grę wchodzą lata 23-29 (po śmierci syna Tyberiusza i uznaniu za następcę tronu Germanika, a przed śmiercią Liwii) lub przy najmocniejszym zawężeniu epoki lata 15-16 (po powrocie Germanika z wyprawy przeciw Germanom, a przed udaniem się na Wschód).

Odkrycie przynależności kamei do czasów dynastii julijsko-klaudyjskiej nie spowodowało usunięcia jej z pochodzącej z czasów bizantyjskich i wzbogaconej o walezjuszowską podstawę oprawy. Nadal tkwiła w relikwiarzu, stanowiąc z nim całość - budujący obraz współistnienia sztuki różnych epok.

W 1791 r. Zgromadzenie Narodowe zadecydowało o sprzedaży obiektów znajdujących się w Sainte-Chapelle. Groźba rozproszenia zgromadzonych skarbów została oddalona dzięki interwencji pozbawionego już wówczas władzy i uwięzionego w Temple Ludwika XVI (1774-1792). Choć wydawałoby się, że głosu obalonego króla występującego w obronie spuścizny po swoich przodkach nikt nie będzie słuchał, to okazał się on skuteczny. Zgodnie z królewskim życzeniem relikwie z Sainte-Chapelle przeniesiono do opactwa Saint-Denis pod Paryżem. „Agat”, czyli Wielką Kameę w relikwiarzu, wraz z innymi cennymi kamieniami oddano do Gabinetu Medali, a manuskrypty do Biblioteki ${ }^{13}$.

12 Szczegółowe identyfikacje poszczególnych postaci i wynikająca $\mathrm{z}$ tego datacja por. J.-B. Giard, Le Grand Camée de France, Paris 1998, 17-23 (monografia wydana w związku z pracami restauratorskimi nad kameą); Le trésor de la Sainte-Chapelle, s. 90-92; Vollenweider - Aviseau-Broustet, Camées et intailles, t. 2, s. 219-220.

${ }^{13}$ Por. Babelon, Catalogue des camées, s. 133; Giard, Le Grand Camée de France, s. 30. 
Niedługo potem oprawa kamei, w otoczce kryminalnego skandalu, przestała istnieć. W nocy z 16 na 17 lutego 1804 r. do Gabinetu Medali włamali się dwaj złodzieje i ukradli eksponaty, za które spodziewali się zyskać najwięcej pieniędzy. Była wśród nich Wielka Kamea. Potraktowano ją w sposób częsty przy rabunku obiektów, których wartość złodzieje oceniają nie podług kryteriów muzealnych, lecz skrajnie materialnych. Z relikwiarza wydobyto wszystkie osadzone w nim perły i szlachetne kamienie, a samą oprawę - sporządzona była z pozłacanego srebra - przetopiono ${ }^{14}$. Gemmę złodzieje próbowali sprzedać w Amsterdamie. Rozpoznał ją jednak francuski konsul, który powiadomił o zaistniałej sytuacji ambasadora. Złodzieje zostali zatrzymani, a Wielka Kamea powróciła do Paryża.

W 1807 r. zamówiono u znanego artysty, ucznia sławnego malarza Davida, Pierre'a Maximiliena Delafontaine'a projekt nowej oprawy kamienia. W żaden sposób nie nawiązywano w nim do przetopionej bizantyjsko-średniowiecznej. Delafontaine sporządził go w panującym wówczas stylu empire. Ponieważ od 1620 r. kamea nie uchodziła już za przedstawienie Józefa na dworze faraona, lecz wizerunek członków pierwszej dynastii rzymskiego cesarstwa, w ornamentyce wykorzystał elementy zaczerpnięte ze sztuki i historii starożytnego Rzymu. Projekt zrealizował w złoconym brązie ojciec Pierre'a Maximiliena, Jean-Baptiste-Maximilien Delafontaine ${ }^{15}$. Już w 1832 r. nowa oprawa przestała jednak odpowiadać gustom epoki. Umieszczono w niej gipsowy odlew kamei, sama kamea zaś eksponowana jest obecnie w wąskiej złotej otoce w swojej nieskażonej późniejszymi dodatkami formie.

Ścisłe odtworzenie wyglądu zniszczonej w 1804 r. oprawy, w jakiej kamea pojawiła się we Francji w XIII w., nie jest możliwe. Jednakże pewne wyobrażenie o niej uzyskać można dzięki opisom zawartym w inwentarzach, czy relacji samego de Peiresca, który nie ograniczył się tylko do nowej interpretacji gemmy, ale poświęcił uwagę również jej oprawie. Z przekazów tych wyłania

${ }^{14}$ Tak samo złodzieje postąpili ze skradzionym razem z Wielką Kameą tzw. Pucharem Ptolemeuszy. Jest to wykonany w sardonyksie antyczny kantharos, który w czasach Karola Łysego (840-877) osadzony został na zdobionej emalią i dużych rozmiarów szlachetnymi kamieniami stopie. Została ona po wydobyciu klejnotów przetopiona i puchar powrócił do Gabinetu Medali bez karolińskiego dodatku, w swojej pierwotnej antycznej formie. Wyrzeźbione w sardonyksie przedstawienia wiążą się z kultem Dionizosa i bogini Demeter. Puchar w pewnej mierze też jest przykładem adaptacji dzieł starożytnej sztuki gliptycznej do tradycji chrześcijańskiej. Podarowany został przez Karola Łysego opactwu w Saint-Denis i przynajmniej od XVII w., a być może już od XV w., podawano w nim królowym Francji Komunię św. pod postacią wina podczas mszy koronacyjnych. Fakt, że puchar z symbolami dionizyjskimi znalazł się w opactwie poświęconym św. Dionizemu, jest raczej tylko zaskakującym, choć wcale nieodosobnionym w historii, zbiegiem okoliczności. Wydaje się, że o włączeniu go do monarszej własności, a potem podarowaniu mnichom do skarbca zadecydowała jego niezwykła uroda. (Le trésor de Saint-Denis. Musée du Louvre. Paris, 12 mars 17 juin 1991, ed. D. Gaborit-Chopin i inni, Paris 1991, 83-87).

${ }^{15}$ Opis i ilustracje przedstawiające oprawę, por. Le trésor de la Sainte-Chapelle, s. 266-267. 
się obraz bogato zdobionego bizantyjskiego relikwiarza ${ }^{16}$. Kamea umieszczona była w kwadratowej drewnianej tablicy pokrytej pozłacanym srebrem. Boki tablicy miały blisko $38 \mathrm{~cm}$. Wysokość całości konstrukcji, wraz z dołączoną przez Karola V baza, wynosiła ok. $60 \mathrm{~cm}$. Baza była szersza od spoczywającego na niej relikwiarza, mierzyła $45 \mathrm{~cm}$. Ozdobiono ją umieszczonymi w gotyckich niszach, wykonanymi w emalii, wizerunkami dwunastu apostołów. Na tablicy wokół kamei znajdowały się liczne relikwie ${ }^{17}$. W czterech kątach oprawy, w strefie ograniczonej przez bordiurę, znajdowały się wizerunki stojących ewangelistów. Każdy z nich trzymał księgę i podpisany był imieniem $^{18}$. W górnej części, poniżej narożników, znajdowały się dwa krzyże. Na prawym przedstawiono stojącą Matkę Bożą i litery MP @Y (skrót od MHTHP

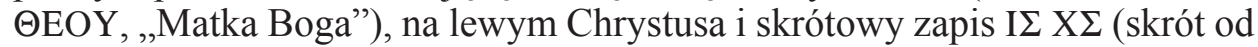
$\mathrm{IH} \Sigma \mathrm{OY} \Sigma \mathrm{XPI} \Sigma \mathrm{TO} \Sigma$, ,Jezus Chrystus”) oraz I $\Delta \mathrm{E}$ OY $\Sigma$ I $\Delta$ OYHM (I $\Delta \mathrm{E}$ O YIO $\Sigma$ $\Sigma$ OY; I $\Delta$ OY H MHTHP $\Sigma$ OY, „oto syn Twój”; „Oto Matka twoja” J 19, 26. 27). Ponadto tablicę ozdabiało dwadzieścia okrągłych medalionów - po pięć na każdym boku. Przedstawiały one podpisane popiersia. Część tych podpisów nie była czytelna dla de Peiresca. Powyżej kamei, w centralnym medalionie ukazano Matkę Bożą, a w medalionach z obu jej stron dwa anioły oraz archaniołów Gabriela i Michała. Pozostałe emalie przedstawiały m.in. Piotra, Jana Chrzciciela, Szymona, Filipa, Pawła, Jerzego, Andrzeja, Zachariasza i Teodora. W relikwiarzu osadzone były także kamienie szlachetne. W podstawie znajdowało się siedem kryształów górskich, a w bizantyjskiej tablicy sześćdziesiąt trzy perły (pierwotnie było ich sześćdziesiąt dziewięć, ale już w XVI w. sześć opraw było pustych), trzy duże szafiry (usytuowane w górnej części relikwiarza), dwadzieścia siedem szmaragdów i dwanaście rubinów ${ }^{19}$.

Jannic Durand, historyk sztuki interesujący się szczególnie sztuką bizantyjską i epoką średniowieczna, wysunął ciekawą hipotezę na temat ewentualnej interpretacji kamei na dworze konstantynopolitańskim. Uznał, że fakt postrzegania jej w Paryżu jako wizerunku tryumfującego w Egipcie Józefa wcale nie musi pochodzić z tradycji bizantyjskiej. Przynajmniej nic tego nie dowodzi. Durand zadaje pytanie, czy ta wspaniała kompozycja ukazując

${ }^{16}$ Najpełniejszą próbę odtworzenia wyglądu relikwiarza wraz z jego rysunkową rekonstrukcją przedstawił Jannic Durand (Le trésor de la Sainte-Chapelle, s. 92-95 i il. 3). Ustalenia Duranda wraz z tekstem przytoczonego przez Babelona (Catalogue des camées, s. 128) inwentarza z $1573 \mathrm{r}$. stanowią podstawę przedstawionej poniżej informacji o średniowiecznej oprawie kamei.

${ }^{17}$ Zgodne z inwentarzem z 1336 r.: ,circa quod erant et sunt plures reliquiae” (,wokół której [tzn. kamei] były i są liczne relikwie”) oraz z $1341 \mathrm{r}$.: ,,unum pulcherrimum camaut in cujus circuitu sunt plures reliquiae” (,jedna bardzo piękna kamea, wokół której są liczne relikwie”).

${ }^{18}$ Wątpliwości budzi jedno imię, które de Peiresc odczytał jako BA $\Sigma \mathrm{H} \Lambda$ (Durand trafnie sugeruje odczytanie: Bazyli) i proponował jego poprawienie na $\Lambda$ OYKA $\Sigma$. Rozbieżność jest jednak znaczna.

${ }^{19} \mathrm{~W}$ inwentarzu z 1573 r. nie wszystkie z tych kamieni zyskały uznanie. Perły określono jako małe, ze szmaragdów tylko pięć oceniono jako dobre, a wszystkie rubiny skwitowano stwierdzeniem, że są małej wartości. Ocena nie może zaskakiwać, gdyż wymagania XVI-wieczne wobec klejnotów były znacznie wyższe niż średniowieczne. 
splendor imperialnego Rzymu nie mogła przypadkiem uchodzić w oczach Bizantyjczyków za przedstawienie Konstantyna Wielkiego i jego matki, św. Heleny ${ }^{20}$. Taka identyfikacja dawałaby podstawy do umieszczenia gemmy w relikwiarzu. Pozwalałaby też podejrzewać, że relikwie, które znajdowały się w oprawie, a o których nic bliższego nie wiadomo, mogły pochodzić z Krzyża Świętego, który miała odnaleźć Helena. Różne fragmenty Krzyża Świętego należały do głównej partii przekazanych przez Baldwina II Ludwikowi IX relikwii. Czy zatem Wielka Kamea znajdowała się wśród nich, lecz pod inną nazwą? Całkowite zniszczenie oprawy w 1804 r. uniemożliwia jednoznaczną odpowiedź.

2. Jowisz z Chartres. Oczywiste są powody zmiany atrybucji kamei z katedry w Chartres z przedstawieniem Jowisza. Sporządzona została ona w sardonyksie o trzech warstwach, najprawdopodobniej w czasach cesarza Tyberiusza (14-37) ${ }^{21}$. Kamień, bez dodanej w średniowieczu oprawy, ma wymiary $9,4 \mathrm{~cm}$ na $6,35 \mathrm{~cm}^{22}$. Wyrzeźbiono w nim postać stojącego Jowisza. W prawej ręce boga znajduje się piorun, lewa ujmuje wysoką laskę-berło. Przy prawej stopie władcy Olimpu widnieje orzeł, który zdaje się spoglądać na oblicze Jowisza. To właśnie orzeł, ptak towarzyszący najwyższemu bóstwu antycznego panteonu, a w tradycji chrześcijańskiej symbolizujący św. Jana Ewangelistę, odpowiada za uznanie tej kamei za wizerunek umiłowanego ucznia Chrystusa.

W XIV w. gemmę osadzono w złotej oprawie. Na przedniej i tylnej powierzchni tej oprawy znajdują się napisy będące cytatami z Nowego Testamentu. Tworzące je litery oraz ich tło wykonano w emalii. Inskrypcja ze strony frontalnej zaczerpnięta została z Ewangelii według św. Łukasza $(4,30)$ i według św. Jana $(18,8)$. Brzmi ona: IESVS AUTEM TRANSIENS PER MEDIVM ILLORUM IBAT („On jednak przeszedłszy pośród nich oddalił się"); ET DEDIT PACEM EIS (,I obdarzył ich pokojem”; zdanie to nawiązuje do Łk 24, 36 i J 20, 19. 21); SI ERGO ME QVERITIS SINITE HOS ABIRE („Jeżeli więc Mnie szukacie, pozwólcie tym odejść!’). Napis na tylnej stronie oprawy pochodzi z początku Ewangelii według św. Jana (1, 1-3): IN PRINCIPIO ERAT VERBVM ET VERBVM ERAT APVD DEVM ET DEVS ERAT EVRBVM HOC ERAT IN PRINCIPIO APVD / DEVM OMNIA PER IPSVM FACTA SVNT ET SINE IPSO FACTVM EST NICHIL (sic!) QVOD FACTVM SET IN IPSO (,Na początku było Słowo, a Słowo było u Boga, i Bogiem było Słowo. Ono było na początku u Boga. Wszystko przez Nie się stało, a bez Niego nic się nie stało, co się stało").

\footnotetext{
${ }^{20}$ Por. Le trésor de la Sainte-Chapelle, s. 94.

${ }^{21}$ Por. Vollenweider - Aviseau-Broustet, Camées et intailles, t. 2, s. 79; inne propozycje datowania to epoka Klaudiusza (41-54) lub II w. cesarstwa (tamże, s. 79-80).

${ }^{22}$ Por. tamże, s. 78.
} 
Dobór napisów wskazuje, że kamea użytkowana była jako amulet ${ }^{23}$. Zdania z przedniej strony oprawy miały chronić właściciela klejnotu przed każdym niebezpieczeństwem. Pierwsze mówiło bowiem o wydostaniu się Jezusa z rąk przeciwników, drugie o pokoju zesłanym po zmartwychwstaniu, a trzecie o bezpieczeństwie, które Chrystus zapewnił swoim uczniom w chwili pojmania go w Ogrójcu. Pierwsze zdania Ewangelii według św. Jana zdobiące drugą stronę oprawy uważano z kolei za posiadające moc odstraszania demonów oraz przeciwdziałania uderzeniom piorunów. Tę ostatnią właściwość w mniemaniu osoby, która poleciła sporządzić z gemmy amulet, miało zapewne jeszcze wzmacniać samo przedstawienie wyryte w sardonyksie. W dłoni „Św. Jana”, który w istocie jest wizerunkiem Jowisza, znajduje się bowiem przynależny temu bogu atrybut - piorun.

Dwa przestawienia liter w cytacie $z$ Ewangelii według św. Jana (EVRBVM zamiast VERBVM i SET zamiast EST) prawdopodobnie nie są przypadkowe. Przeciwko uznaniu ich za zwykły błąd przemawia wielka staranność, z jaką cała inskrypcja została sporządzona. Zamiana liter mogła pełnić jakąś magiczną rolę w amulecie ${ }^{24}$.

Barwa tła napisów - czerwona i czarna, współgra z dwoma z trzech kolorów sardonyksu. Sam kamień według poematu biskupa Rennes, Marboda (zm. 1123), miał obdarowywać swojego właściciela cnotą pokory, czystości i powściagliwości ${ }^{25}$. W parafrazie tego utworu każdej barwie sardonyksu - bieli, czerni i czerwieni, przypisane zostało symboliczne znaczenie:

„Sardoniks barwy troistej,

Jak człowiek wewnętrznie czysty,

Pozornie stawia się w cieniu,

A białość nosi w sumieniu.

Gwoli tak świętej naturze

W męczeńskiej zalśni purpurze"26.

$\mathrm{Na}$ frontalnej inskrypcji w XVIII w. umieszczono trzynaście heraldycznych kwiatów dynastii Kapetyngów, lilii, oraz w dolnej części owalu nawiązujące do tytułu następców tronu Francji dwa delfiny. W konsekwencji część liter napisu nie jest widoczna. Choć ozdoby te przeniesiono na oprawę dopiero

${ }^{23}$ Dokładny opis średniowiecznej oprawy gemmy oraz ochronnego charakteru otaczających ją tekstów por. Babelon, Catalogue des camées, s. 1-3.

${ }^{24}$ Por. tamże, s. 3.

${ }^{25}$ Marbodus, De lapidibus pretiosis Encheridion, ed. w: Marbodei Galli poetae vetustissimi de lapidibus pretiosis Encheridion cum scholiis Pictorii Villingensis. Eiusdem Pictorii de lapide molari carmen, [Freiburg] 1531, 50v: „Hic humilem castumque facit, multumque pudicum”.

${ }^{26}$ Marbodus Redonensis (?), Lapidarium 31-36, PL 162, 1581B (Anselmus Laudunensis, Enarrationes in Apocalypsin 22), thum. E. Porębowicz: Marbod z Rennes (?), Lapidarium, w: Muza chrześcijańska, t. 2: Poezja łacińska starożytna i średniowieczna, wstęp, red. i oprac. M. Starowieyski, OŻ 10, Kraków 1992, 293; nie ma pewności, czy autorem parafrazy był także sam Marbod. 
w czasach nowożytnych, to ich stylistyka wskazuje, że również pochodzą z jakiegoś obiektu wykonanego w XIV wieku.

Rolę prywatnego amuletu klejnot przestał pełnić w czasach Karola V Mądrego. Władca ten ofiarował kameę z uznawaną za św. Jana postacią katedrze w Chartres w celu ozdobienia nią relikwiarza zawierającego koszulę Najświętszej Maryi Panny. Prawdopodobnie miało to miejsce 30 czerwca 1367 r., gdyż wówczas Karol V odbył pielgrzymkę do Chartres ${ }^{27}$. Dar swój Walezjusz kazał upamiętnić dołączeniem do oprawy gemmy inskrypcji wzbogaconej o królewskie emblematy. Napis umieszczony jest w dolnej części owalu kamienia. Wieńcząca tekst otwarta korona królewska spoczywa na wcześniej sporządzonej oprawie kamei, a poniżej królewskiego napisu dedykacyjnego znajduje się tarcza herbowa dynastii francuskiej. Przedstawia ona złote lilie na ciemnobłękitnym tle. Inskrypcja przekazuje wiadomość, że: charles roy de france / fils du roy jehan donna / ce joyau l'an m ccc lxvii / le quart an de son regne („Karol, król Francji, syn króla Jana, ofiarował ten klejnot w roku 1367, czwartym roku swojego panowania"). Kamea zdobiła relikwiarz do 17 września 1794 r. Tego dnia w ramach przejmowania podczas Rewolucji Francuskiej własności kościelnej przeniesiona została do Gabinetu Medali ${ }^{28}$.

3. Ametyst ewangeliarza z Sainte-Chapelle. O ile nie trudno zrozumieć, że przedstawienie Jowisza, ze względu na towarzyszącego bóstwu orła, zostało w chrześcijańskim świecie obrazów odczytane jako wizerunek ewangelisty Jana, o tyle nie można znaleźć prostego i jednoznacznego wyjaśnienia, dlaczego intaglio ukazujące cesarza Karakallę (211-217) uznano za podobiznę św. Piotra. Gemma ta osadzona była w przedniej części wykonanej z pozłacanego srebra oprawy ewangeliarza z Sainte-Chapelle. Zajmowane przez nią miejsce w repusowanej oprawie ściśle wiąże się z symboliką całości obrazu. Tematem jego jest Ukrzyżowanie. Pod ramionami krzyża stoją Matka Boża i św. Jan, powyżej jego ramion ukazano słońce i księżyc (ten widnieje w swoich dwóch postaciach - półksiężyca i pełni), a intaglio umieszczone zostało poniżej pionowej belki krzyża. Ten wznosi się zatem ku górze wsparty na wizerunku św. Piotra. Sens przekazu jest oczywisty, obraz ma ilustrować słowa Mt 16, 18: „Ty jesteś Piotr [czyli Skała], i na tej Skale zbuduję Kościół mój, a bramy piekielne go nie przemogą". Rozpięte na krzyżu ręce Chrystusa, ponad którymi znajdują się słońce i księżyc, symbolizują rozprzestrzenianie na cały świat prawd głoszonych przez Kościół.

Gemma nie stanowiła w scenie z ewangeliarza elementu wyłącznie ozdobnego. Była integralną częścią religijnej symboliki dzieła. Wykorzystanie jej w sporządzonej w czasach Ludwika IX, po 1245 a przed 1248 r. oprawie ${ }^{29}$

${ }^{27}$ Por. Babelon, Catalogue des camées, s. 4.

${ }^{28}$ Vollenweider - Aviseau-Broustet, Camées et intailles, t. 2, s. 78.

${ }^{29}$ Por. Le trésor de la Sainte-Chapelle, s. 154; Vollenweider - Aviseau-Broustet, Camées et intailles, t. 2, s. 182. 
było jednak możliwe dzięki temu, że w jakimś momencie swego istnienia przeszła znaczeniową metamorfozę i z podobizny Karakalli stała się portretem św. Piotra. W swej schrystianizowanej postaci dotarła do Francji. Nie jest wykluczone, że przywieziona została z Konstantynopola wraz z relikwiami, które cesarz Baldwin II przekazał królowi Ludwikowi. Wizerunek św. Piotra widzieli w niej Bizantyjczycy. Możliwe, że to oni, jeśli nie chrześcijanie z okresu późnego cesarstwa rzymskiego, umieścili na niej odpowiedni podpis.

$\mathrm{Na}$ wygrawerowanym $\mathrm{w}$ ametyście intaglio $\mathrm{w}$ rzeczywistości ukazany jest lewy profil Karakalli. Cesarz nosi spięte okrąłą broszą charakterystyczne dla jego przedstawień paludamentum, wojskowy płaszcz rzymskiego wodza naczelnego ${ }^{30}$, który jako sagum purpureum był jedną z zewnętrznych oznak cesarskiej władzy. Imperialną symbolikę okrycia i samego portretu potęguje sporządzenie go w kamieniu uważanym za najcenniejszy w grupie purpurowych $-\mathrm{w}$ ametyście.

Przedstawienie władcy odbiega w pewnych detalach od najbardziej rozpowszechnionego na monetach, gemmach i rzeźbach wizerunku. Twarz Karakalli ukazywana była zazwyczaj w formach prawie kubistycznych. Profil jego określany jest jako profil „boksera”. Na intaglio osadzonym w ewangeliarzu cechy te nie są zauważalne. Czoło władcy jest wysokie, brew wznosi się nad dużym okiem łagodnym długim półkolem (w typowych wizerunkach brwi są ściagnięte, co nadaje twarzy wyraz napięcia, a nawet okrucieństwa), nos długi i spiczasty. Ponadto głowa nie jest ozdobiona wieńcem. Ten brak wieńca oraz odmienność formalna w porównaniu $\mathrm{z}$ najczęstszymi przedstawieniami spowodowała, że niektórzy z badaczy uważaja, iż intaglio ukazuje portret nie Karakalli, lecz jego młodszego brata Gety ${ }^{31}$ (zm. 212). Identyfikacji z Karakallą nie można jednak stanowczo odrzucić. Profil uwieczniony na gemmie wykazuje bowiem cechy wspólne z młodzieńczymi portretami cesarza oraz z jego wizerunkami na monetach wybijanych w Azji Mniejszej32.

Zarówno jakość, jak i rozmiary ametystu są znaczące - wysokość to $4 \mathrm{~cm}$, a szerokość $2,9 \mathrm{~cm}^{33}$. Ścisłe ustalenie daty powstania gliptycznego dzieła nie jest możliwe. Proponowany jest początek samodzielnych rządów Karakalli, ok. roku $212^{34}$, ale niepewność identyfikacji portretowanego władcy utrudnia dokładniejszą chronologię.

${ }^{30} \mathrm{Na}$ intaglio paludamentum spięte jest na lewym ramieniu, a nie - jak to było praktykowane - na prawym. Trzeba jednak pamiętać, że rytowane wklęśle gemmy służyły jako pieczęcie. W wykonanym zaś odcisku uzyskiwane jest lustrzane odbicie przedstawienia. W efekcie lewe ramię sportretowanego na gemmie stawało się w odciśniętym materiale ramieniem prawym.

${ }^{31}$ Por. Le trésor de la Sainte-Chapelle, s. 158; Vollenweider - Aviseau-Broustet, Camées et intailles, t, 2, s. 183.

${ }^{32}$ Por. Le trésor de la Sainte-Chapelle, s. 158; Vollenweider - Aviseau-Broustet, Camées et intailles, t, 2, s. 183.

${ }^{33}$ Por. Le trésor de la Sainte-Chapelle, s. 154; Vollenweider - Aviseau-Broustet, Camées et intailles, t. 2, s. 182.

${ }^{34}$ Por. Le trésor de la Sainte-Chapelle, s. 154. 
Podobnie nie sposób ustalić, czy gemma została przekształcona w wizerunek św. Piotra jeszcze w czasach cesarstwa rzymskiego, czy dopiero w epoce bizantyjskiej. „Zamiana” postaci jednak nastąpiła i to w sposób jednoznaczny i kategoryczny. Przed profilem sportretowanego mężczyzny wyryto napis O ПЕТРО $\Sigma$ („Piotr”), a przy plecach - krzyż.

Jakie mogły być powody takiej atrybucji? Ukazany na intaglio mężczyzna ma proste, nieco surowe rysy. Wspomniany brak na jego głowie cesarskiego wieńca wzmacnia emanujące $\mathrm{z}$ wizerunku wrażenie szorstkiej prostoty i bezpośredniości. Mógł zatem pasować do wyobrażenia apostoła, który zanim został rybakiem łowiącym ludzi (por. Łk 5, 10) był rybakiem wcale nie w przenośnym znaczeniu tego słowa. Materiał, w jakim wykonano intaglio, w sferze chrześcijańskiej symboliki szlachetnych kamieni mocno związany był $\mathrm{z}$ apostołami ${ }^{35}$. Fiolet w purpurze ametystu łączono $\mathrm{z}$ takimi cnotami jak pokora, skromność i powściagliwość. Barwa ta odzwierciedlała również mękę Chrystusa oraz śmierć męczeńską tych, którzy szerzyli wiarę. Przysługującą w starożytności władcom purpurę ametystu chrześcijaństwo przekazało apostołom jako tym, którzy głosili Ewangelię i dawali jej świadectwo ofiarą własnej krwi. Byli przecież na tej Ziemi przedstawicielami Królestwa Bożego.

Przekształcenie wizerunku rzymskiego władcy w apostoła Piotra niekoniecznie musiało wynikać z niewiedzy w kwestii pierwotnego przekazu ikonograficznego gemmy. Zmiana ta dokonała się we wschodniej części dawnego Imperium Rzymskiego, a tam przykład świadomej adaptacji przedstawień dawnych bóstw dał sam Konstantyn Wielki. Zosimos przekazuje, że zakładając nową stolicę władca kazał wznieść dwie świątynie poświęcone bóstwom opiekuńczym Rzymu i Konstantynopola. Ten drugi przybytek ozdobiono posagiem, który pierwotnie przedstawiał boginię Reę. Cesarz polecił usunąć z niego dwa umieszczone po bokach lwy i zmienić ustawienie rąk bóstwa. Ostatecznie dawna podobizna Rei została przekształcona w Tyche Konstantynopola. Opiekunka stolicy przybrała postać spoglądającej na miasto, modlącej się kobiety ${ }^{36}$.

Oryginalne ametystowe intaglio nie zdobi obecnie ewangeliarza z Sainte-Chapelle. W 1834 r. zostało ono usunięte z oprawy i przekazane do wchodzącego w skład francuskiej Biblioteki Narodowej Gabinetu Medali ${ }^{37}$. Miejsce jego w ewangeliarzu zajęła wykonana w barwnym szkle imitacja.

4. Akwamaryn Euodosa. Antyczne intaglio z akwamarynu w oprawie z szafirów i pereł jest drobna, choć niezwykle cenną, pozostałością po nieistniejącym już niezwykłym obiekcie z epoki karolińskiej znanym pod nazwą

${ }^{35}$ Szerokie objaśnienie chrześcijańskiej symboliki ametystu, por. S. Kobielus, Lapidarium christianum. Symbolika drogich kamieni. Wczesne chrześcijaństwo i średniowiecze, Kraków 2012, 101-104.

${ }^{36}$ Por. Zosimos, Historia nova II 31, 2-3.

${ }^{37}$ Por. Le trésor de la Sainte-Chapelle, s. 154; Vollenweider - Aviseau-Broustet, Camées et intailles, t. 2, s. 182. 
Escrain de Charlemagne. Gemma stanowiła zwieńczenie jego ażurowej, wykonanej ze złota, pereł i szlachetnych kamieni konstrukcji. Ten rodzaj przejrzystego ekranu osadzony był na relikwiarzowej skrzynce $\mathrm{z}$ pozłacanego srebra $^{38}$. Wyniesienie gemmy na szczyt dzieła było konsekwencją uznawania uwiecznionego w niej kobiecego profilu za podobiznę Matki Bożej. W rzeczywistości jest to portret Julii, córki cesarza Tytusa (79-81). Akwamaryn, bez dodanej do niego w późniejszym okresie oprawy, mierzy $5 \mathrm{~cm}$ wysokości oraz 3,7 cm szerokości. Jest to gliptyczne arcydzieło. Doskonałą technikę i drobiazgowość wykonania zauważa się lepiej, ze względu na rozpraszający nieco wzrok połysk kamienia, na sporządzonym z niego odcisku ${ }^{39}$. Autorem grawerunku był działający na dworze Flawiuszy, a potem także pierwszych władców dynastii Antoninów Euodos. Podpisał on swoje dzieło - za plecami Julii widać inskrypcję: EYO $\Delta \mathrm{O} \Sigma$ EПOIEI (,wykonał Euodos”). Intaglio należy zapewne datować na ok. 90 rok $^{40}$. Po śmierci Tytusa jego brat, cesarz Domicjan (81-96), skłonił Julię do zostania jego kochanką. Gdy zaszła w ciążę, nakazał, aby usunęła płód. W wyniku komplikacji wywołanych aborcją Julia zmarła. Było to w roku 91. Stryj-kochanek, odczuwając być może jakieś wyrzuty sumienia, przeprowadził w senacie jej ubóstwienie.

Ponieważ Escrain, mimo swojej nazwy, pochodzi dopiero z okresu Karola Łysego (840-877), a jego powstanie datowane jest ściślej na lata 870-87741, to na pewno wówczas widziano już w gemmie portret Matki Bożej. To bowiem grecki grawerunek na stanowiącym górną część oprawy akwamarynu szafirze jednoznacznie określa podobiznę jako Matkę Bożą. Szafir nosi na sobie mono-

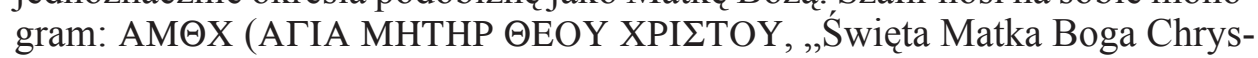
tusa") oraz przedstawienie delfina, który we wczesnochrześcijańskiej sztuce symbolizował Chrystusa Zbawiciela. Chociaż zarówno zachowany niewielki fragment dawnego Escrain, jak i znana z rysunku jego całość datowana jest na okres karoliński, to ze względu na ten wyraźny element bizantyjski warto się zastanowić, czy dzieło nie pochodziło, przynajmniej w pewnych partiach, ze sztuki wschodniej części późnego Imperium Rzymskiego lub wczesnośredniowiecznych ośrodków władzy Bizancjum na Zachodzie. Do takich najbardziej znanych obszarów należał Egzarchat Rawenny. Wszelkie badania utrudnione są jednak z powodu zniszczenia przeważającej partii zabytku.

W zachowanej oprawie samego akwamarynu główną rolę pełnią tylko dwa rodzaje kamieni - szafiry i perły. Gemma otoczona jest dziewięcioma szafirami. Dwa dolne są do siebie zbliżone i łączyły szczyt konstrukcji z resztą dzieła. Każdy z pozostałych szafirów ozdobiony jest jakby wyrastająca z niego przekłutą perłą. Taka perła znajdowała się także przy górnym kamieniu, ale

\footnotetext{
${ }^{38}$ Dokładny opis zabytku, por. Le trésor de Saint-Denis, s. 92-94.

${ }^{39}$ Por. Vollenweider - Aviseau-Broustet, Camées et intailles, t. 2, s. 89, il. 145.

${ }^{40}$ Por. tamże, s. 129.

${ }^{41}$ Por. tamże, s. 128.
} 
obecnie jej brakuje. Oprawa intaglio liczy sobie 10,5 cm wysokości (pierwotnie była wyższa o niezachowaną perłę) i $9,5 \mathrm{~cm}$ szerokości ${ }^{42}$.

Po raz pierwszy Escrain z Saint-Denis wzmiankowany jest w początkach $\mathrm{X}$ w. Nazwano go wówczas gipsa. Wysuwana sugestia, że był to zapis błędny, a słowo powinno brzmieć capsa ${ }^{43}$ (,skrzynka”, „puszka na relikwie”), nie jest uzasadniona. Gypsum w łacinie kościelnej może oznaczać urnę, w której przechowywano krew męczenników. Słowo bez wprowadzania poprawek ma zatem ten sam sens co capsa. Całość Escrain bierze w tym przypadku nazwę od podstawy - relikwiarza, który zawierał szczątki świętych Jerzego, Teodora i Apolinarego. Z kolei górna jego część zadecydowała o określeniu crista nadanym mu przez Sugera. Ten najsławniejszy z opatów Saint-Denis (pełnił swoją funkcję w latach 1122-1151) zachwycał się ognistymi blaskami kamieni arcydzieła złotników, które zdobiło ołtarz bazyliki. Słowo crista oznacza „czub” u ptaków, także „pióropusz”, „kitę” na hełmie oraz „szczyt” pasma górskiego. W tym wypadu odnosiło się do ażurowej konstrukcji „,wyrastającej" z relikwiarza.

Sformułowanie éscrain $\mathrm{w}$ odniesieniu do zabytku pojawiło się dopiero w Grandes Chroniques de France. Powstały w XV w. tekst prawidłowo przypisywał przekazanie relikwiarza do opactwa Karolowi Łysemu i w związku z tym nazywał go Escrain Kalle. Kalle jest północnogermańską odmianą imienia Karl. Dopiero w wieku XVI, zapewne w celu przydania relikwiarzowi większej chwały kosztem historycznej prawdy, zaczęto określać go mianem Escrain de Charlemagne, przypisując jego pochodzenie nie czasom Karola Łysego, lecz Karola Wielkiego (768-814). Słowo éscrain w zaskakujący sposób powiela dwoistość średniowiecznych nazw zabytku - gipsa i crista. Można je bowiem rozumieć jako pochodzące od łacińskiego scrinium współczesne écrin, „skrzynka, szkatułka” - i najczęściej tak tłumaczy się nazwę zabytku lub biorące początek z niderlandzkiego scherm przez francuskie XIII-wieczne escren, współczesne écran, „ekran, parawan”44.

Dolna część skrzyni relikwiarzowej została przerobiona w okresie pełnienia funkcji opata przez Philippe'a de Vilette (1398-1418). Upamiętniono to umieszczeniem na dziele jego herbu. W tej postaci Escrain de Charlemagne przetrwał do czasów Rewolucji. Pierwsze jego naruszenie nastąpiło w 1791 r., kiedy intaglio z akwamarynu wraz z jego oprawą usunięto ze szczytu relikwiarza i przekazano do Gabinetu Medali. Ostateczne unicestwienie reszty zabytku nastąpiło w 1794 r. Ogromna liczba drogocennych klejnotów zawartych w Escrain miała dla borykającej się z finansowymi problemami władzy większe znaczenie niż wartość historyczna dzieła, związana na dodatek z tradycjami religijnymi, od których rewolucjoniści się odcinali. Kamienie zostały

${ }^{42}$ Por. Le trésor de Saint-Denis, s. 95.

${ }^{43}$ Por. tamże, s. 94.

${ }^{44}$ Le Petit Robert. Dictionnaire alphabétique et analogique de la langue française, texte remanié et amplifié sous la dir. de J. Rey-Debove - A. Rey, Paris 2013, s.v. écrin i écran. 
wydobyte z opraw i sprzedane, a szlachetne kruszce przetopiono. Wizerunek Escrain znany jest dzięki pochodzącej z 1791 r. akwareli namalowanej przez Etienne-Eloi Labarre'a. Ponieważ zabytek przedstawiony został na niej w połowie swojej wielkości można ustalić jego rzeczywiste wymiary. Było to dzieło imponujące. Wysokość jego przekraczała $114 \mathrm{~cm}$, a szerokość $83 \mathrm{~cm}^{45}$. Dzięki spisowi kamieni, które pozyskano z Escrain w celu sprzedaży, wiadomo, że zdobiło go ponad siedemset pereł, dwieście dziewięć szafirów, sto trzydzieści pięć szmaragdów, dwadzieścia dwa granaty, jedenaście ametystów, osiem rubinów i dwa akwamaryny ${ }^{46}$.

Względy, które zadecydowały o uznaniu intaglio z portretem córki cesarza Tytusa, Julii, za podobiznę Matki Bożej, nie są jasne. Powody sporządzenia z szafirów i pereł oprawy, jaką gemma uzyskała dzięki nadanej jej nowej atrybucji, łatwo jednak zrozumieć w oparciu o chrześcijańską symbolikę klejnotów. Szafir i perła to kamienie powiązane z Chrystusem i Matką Bożą. Ze względu na swoją barwę szafir kojarzony był z niebem, oznaczał niebiańskie cnoty i mądrość spływającą na ludzi dzięki Bożej łasce ${ }^{47}$. Miał odwracać od spraw ziemskich i kierować ludzi na drogę miłości niebiańskiej. W przypisywanym Marbodowi Lapidarium kamień ten przypomina o Królestwie Bożym:

„Szafir ma barwę ozdobną,

Tronowi niebios podobna;

Oznacza serca prostote

A w niej nadziei ochotę,

Życiem i czyny zacnymi

Rozbłyskującą śród ziemi”48.

Biel pereł odzwierciedla czystość Matki Bożej. Jednocześnie perłą jest sam Chrystus ${ }^{49}$. W alegorycznej interpretacji przyrody zawartej w pochodzącej zapewne z II w. najstarszej redakcji Fizjologa Matka Boża jest muszla, która dzięki boskiej błyskawicy urodziła perłę - Chrystusa ${ }^{50}$. Szczególnie perłę przekłuta, a właśnie takie otaczają gemmę z akwamarynu, kojarzono z Jezusem. Najpełniejszy wyraz symbolika ta znalazła w Pieśniach o perle św. Efrema (zm. 373). W dwóch strofach drugiej pieśni tego utworu tak oddana została relacja perły i Chrystusa:

${ }^{45}$ Por. Le trésor de Saint-Denis, s. 92.

${ }^{46}$ Por. tamże.

${ }^{47}$ Symbolika szafiru, por. Kobielus, Lapidarium christianum, s. 70-73; S. Malaguzzi, Bijoux, pierres et objets précieux, trad. par C. Mulkai, Paris 2008, 328-331.

${ }^{48}$ Marbodus Redonensis (?), Lapidarium 13-19, PL 162, 1580D - 1581A (Anselmus Laudunensis, Enarrationes in Apocalypsin 22), OŻ 10, 292.

${ }^{49}$ Interpretacja perły, por. Kobielus, Lapidarium christianum, s. 154-158; Malaguzzi, Bijoux, pierres et objets précieux, s. 357-363.

${ }^{50}$ Por. Phisiologus I 44C, 2. 
„Z natury podobna jesteś w cierpliwości

do milczącego Baranka.

Przebita zwisasz z uszu

jak Chrystus na Golgocie,

zlewając światło na patrzących".

„W twym pięknie widać piękno Syna,

co okrył się cierpieniem.

Jego przeszyły gwoździe - ciebie igła.

Przez mękę stał się Królem -

cierpienie pomnożyło i twe piękno"51.

Perły i szafiry w zachowanej oprawie akwamarynu nie służyły wyłącznie ozdobie. Harmonizowały z domniemanym portretem Matki Bożej, stanowiły cenne i stosowne dla niego ,tło”. Zdecydowana dominacja pereł (ponad siedemset) i szafirów (dwieście dziewięć) w całości Escrain de Charlemagne zapewne też nie była przypadkowa. Wybrano je jako najbardziej właściwe do wyeksponowania, a ściślej wyniesienia wzwyż, wizerunku, w którym widziano oblicze Matki Chrystusa.

$* * *$

Wśród przyczyn adaptacji dzieł sztuki pogańskiej do potrzeb kultu chrześcijańskiego znaczną rolę odgrywały względy estetyczne. Przejmowano nie tylko takie obiekty, które dzięki pewnym elementom można było odczytać inaczej niż było to w obrębie kultury, w jakiej powstały. Nadawano pogańskim wytworom sztuki nowe znaczenia, wprowadzano je do kształtującej się tradycji i widziano w nich to, co widzieć chciano. Artystyczne walory powodowały, że obiekty funkcjonujące w kręgu kultury pogańskiej znalazły swoje miejsce także w kulturze chrześcijańskiej.

\section{CHRISTIAN INTERPRETATION OF SOME ANCIENT GEMS}

\section{(Summary)}

The article presents the Christian interpretation of four ancient gems from the collection of Cabinet des médailles (department of French National Library). Next to the role of the objects in medieval tradition the history of the gems is presented. An attempt at explaining the reasons of using the gems in Christian cult is made.

${ }^{51}$ Ephraem Syrus, Hymnus 82 (De Margarita II) 11-12, ed. E. Beck, CSCO 154, Louvain 1955, 252, thum. W. Kania: Św. Efrem Syryjski, Pieśni o perle, w: Muza chrześcijańska, t. 1: Poezja armeńska, syryjska i etiopska, red. i oprac. M. Starowieyski, OŻ 6, Kraków 1985, 196. 
Key words: ancient gems, medieval tradition, medieval reliquaries, symbolism of gemstones.

Słowa kluczowe: gemmy antyczne, tradycja średniowieczna, średniowieczne relikwiarze, symbolika kamieni szlachetnych.

\section{BIBLIOGRAFIA}

\section{Źródła}

Ephraem Syrus, Hymnus 82 (De Margarita II), ed. E. Beck, CSCO 154, Louvain 1955, 251-254, tłum. W. Kania: Św. Efrem Syryjski, Pieśni o perle, w: Muza chrześcijańska, t. 1: Poezja armeńska, syryjska i etiopska, red. i oprac. M. Starowieyski, OŻ 6, Kraków 1985, 191-205.

Clemens Alexandrinus, Paedagogus I: ed. H.I. Marrou - M. Harl, SCh 70, Paris 1960, II: ed. C. Mondésert - H.I. Marrou, SCh 108, Paris 1965, II: ed. C. Mondésert - C. Matray - H.I. Marrou, SCh 158, Paris 1970, tłum. M. Szarmach: Klemens Aleksandryjski, Wychowawca, Torun 2012.

Marbodus Redonensis (?), Lapidarium, PL 162, 1580D - 1582A (Anselmus Laudunensis, Enarrationes in Apocalypsin 22), thum. E. Porębowicz: Marbod z Rennes (?), Lapidarium, w: Muza chrześcijańska, t. 2: Poezja łacińska starożytna i średniowieczna, wstęp, red. i oprac. M. Starowieyski, OŻ 10, Kraków 1992, 292-294.

MARBodei Galli poetae vetustissimi de lapidibus pretiosis Encheridion cum scholiis Pictorii Villingensis. Eiusdem Pictorii de lapide molari carmen, [Freiburg] 1531.

\section{Opracowania}

Babelon E., Catalogue des camées antiques et modernes de la Bibliothèque Nationale, Paris 1897.

Giard J.-B., Le Grand Camée de France, Paris 1998.

KIng C. W., Antique Gems, their Origin, Uses, and Value as Interpreters of Ancient History, and as Illustrative of Ancient Art., London 1860.

KobIeLus S., Lapidarium christianum. Symbolika drogich kamieni. Wczesne chrześcijaństwo i średniowiecze, Kraków 2012.

Le Petit Robert. Dictionnaire alphabétique et analogique de la langue française, texte remanié et amplifié sous la dir. de J. Rey-Debove - A. Rey, Paris 2013.

Le trésor de la Sainte-Chapelle. Paris, Musée du Louvre, 31 mai 2001 - 27 août 2001, éd. J. Durand - M.-P. Lafitte, Paris 2001.

Le trésor de Saint-Denis. Musée du Louvre. Paris, 12 mars - 17 juin 1991, éd. D. GaboritChopin i inni, Paris 1991.

Malaguzzi S., Bijoux, pierres et objets précieux, trad. par C. Mulkai, Paris 2008.

Mersan M. Du, Histoire du Cabinet des Médailles, Antiques et Pierres Gravées, avec une notice sur la Bibliothèque Royale et une description des objets exposés dans cet établissement, Paris 1838.

PYsiak J., Król i Korona Cierniowa. Kult relikwii we Francji Kapetyngów, Warszawa 2012.

Sena Chiesa G., Nova gloria vetustatis. Intailles et camées dans la Croix de Didier de Brescia, w: La glyptique des mondes classiques. Mélanges en hommage à MarieLouise Vollenweider, textes réunis par M. Aviseau Broustet, Paris 1997, 97-117.

Vollennweider M.-L. - Aviseau-Broustet M., Camées et intailles, t. 2: Les Portraits du Cabinet des médailles. Catalogue raisonné. Planches, Paris 2003. 


\section{ANEKS}

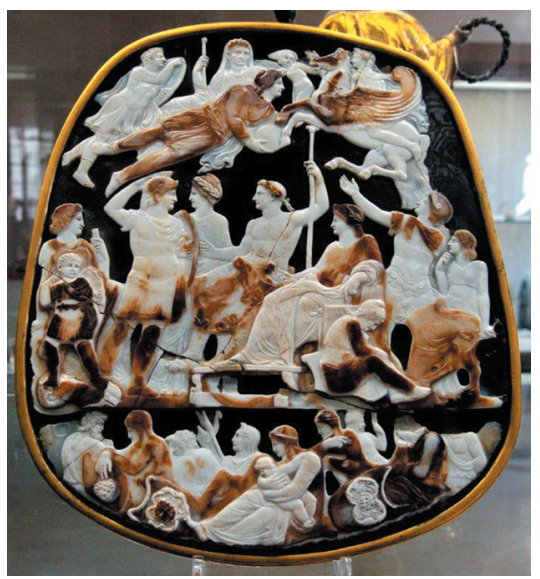

Il. 1. Wielka Kamea Francji, sardonyks, źródło: https://upload.wikimedia.org/wikipedia/ commons/8/87/Great_Cameo_of_France_CdM_Paris_Bab264_n1.jpg.

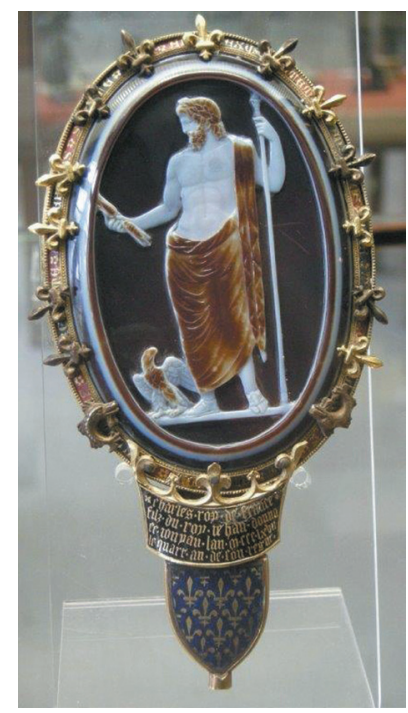

Il. 2. Jowisz z Chartres, sardonyks, źródło: https://upload.wikimedia.org/wikipe$\mathrm{dia} / \mathrm{commons} / \mathrm{c} / \mathrm{ce} / \mathrm{CdM} \% 2 \mathrm{C} \_$cammeo_di_chartres$\% 2 \mathrm{C}$ giove_con_l'aquila $\% 2 \mathrm{C}$ _ _ sec._d.c.\%2C_sardonice.JPG. 


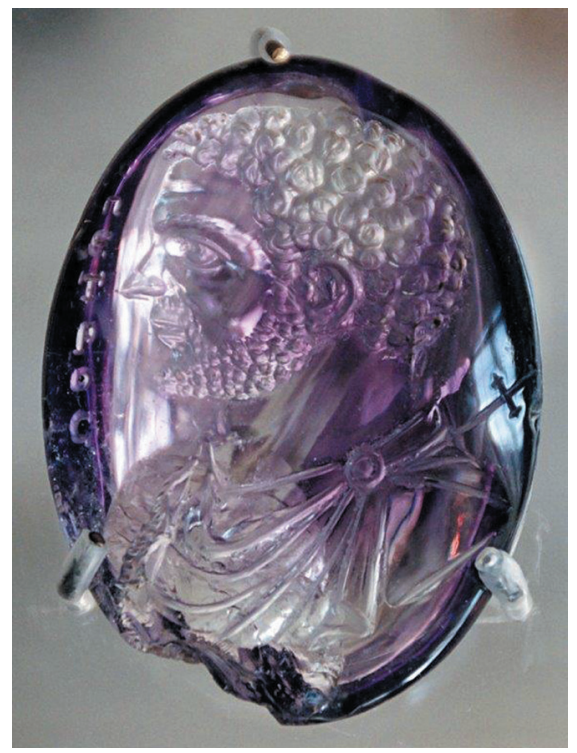

Il. 3. Cesarz Karakalla na wykonanym w ametyście intaglio, źródło: https://upload. wikimedia.org/wikipedia/commons/a/a4/Intaglio_Caracalla_Cdm_Paris_Chab2101.jpg.

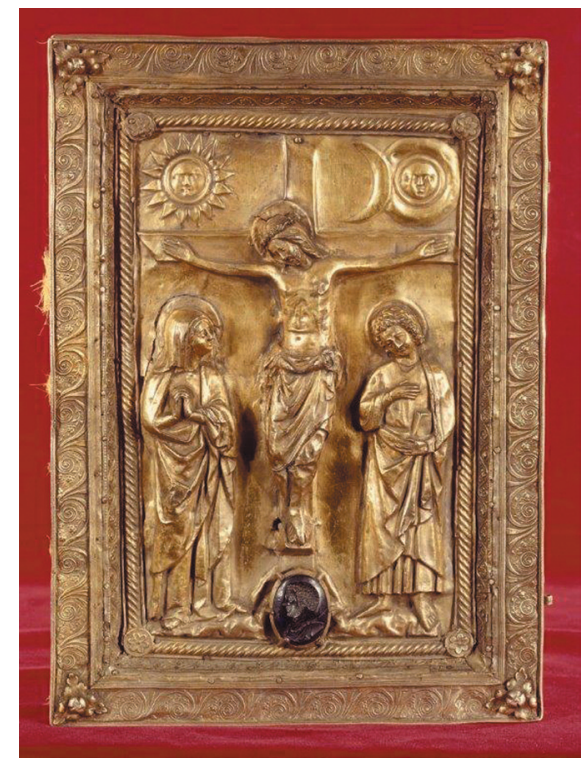

Il. 4. Ewangeliarz z Sainte-Chapelle, źródło: http://www.medievalhistories.com/wpcontent/uploads/16-Deuxi\%C3\%A8me-\%C3\%A9vang\%C3\%A9liaire-de-la-Sainte-Chapelle_BNF.jpg?eb04ee. 


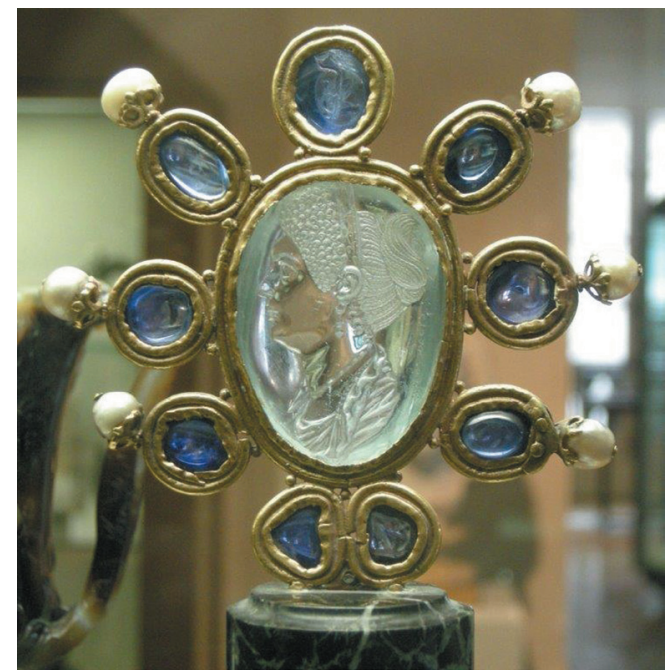

Il. 5. Julia, córka cesarza Tytusa, na intaglio wykonanym w akwamarynie, źródło: https://upload.wikimedia.org/wikipedia/commons/b/be/CdM\%2C_intaglio_di_ giulia $\% 2 \mathrm{C}$ figlia_di_tito $\% 2 \mathrm{C}$ _seconda_met $\% \mathrm{C} 3 \% \mathrm{~A} 0$ del_I_secolo_dc. $\% 2 \mathrm{C}$ acqua-

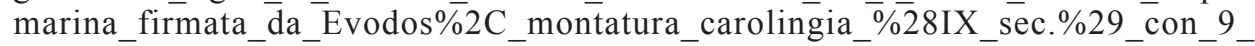
zaffiri_e__6_perle.JPG ?uselang=fr.

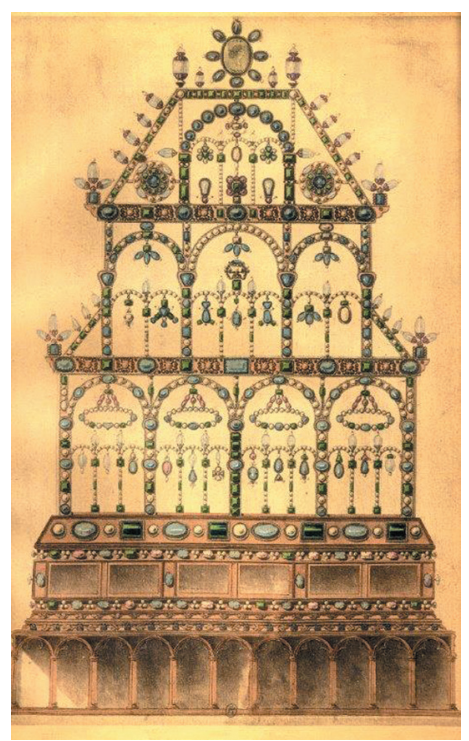

Il. 6 Escrain de Charlemagne, akwarela E.-E. Labarre’a z 1791 r., źródło: http://www. medart.pitt.edu/image/France/St-denis/felebien/Piersac/PiersacScreenCharl-big.jpg. 
